\title{
年間を通じたゲルと固定家屋の利用実態
}

中国・内モンゴル自治区東ウジュムチン旗における牧畜民の定着化と居住環境変化

\section{ACTUAL USAGE OF FIXED HOUSES AND “GER” THROUGHOUT THE YEAR} Settling and changes of living environments of pastoralists in East Ujimqin Banner, Inner Mongolia, China

\author{
野村理恵*, 中山 徹**
}

\section{Rie NOMURA and Toru NAKAYAMA}

\begin{abstract}
This paper analyzed the changes of living environments by the settling of Mongolian people focusing on the separation of fixed houses and Ger. 1) Because the clear borderlines were drawn between each households' land in the 1980s, the travel distances have drastically decreased from some hundred kilometers to some kilometers. 2) Within the limited pasture areas, the location of fixed houses and how often and when they temporarily move are determined in view of problems such as population growth, grass damage and fountainhead lack. Ger was, therefore, used during all seasons on the short- to long-term based although fixed houses are pervasive throughout the region. 3) Both tendencies were found at the same time; reduction and simplification of Ger utilization and possession and application of traditional Ger due to the settling.
\end{abstract}

Keywords :Ger, Mobile pasturage, Settlement, Inner Mongolia ゲル，移動放牧，定着化，内モンゴル

\section{1. はじめに}

\section{1-1. 研究の目的}

本論は，中国・内モンゴル自治区のモンゴル族牧畜民を対象とし， 定着化に伴う居住環境の変化について, 移動住居であるゲル注1) ger と固定家屋であるバイシン注2) baising の利用実態及び使い分けに着目 して明らかにすることを目的とする。

内モンゴル自治区における牧畜民の定着化は，農耕化，漢族の流 入等の影響により徐々に進行し，特に中華人民共和国成立以降は大 躍進政策，人民公社化運動，改革開放政策等に基づく生産体制の変 化により大きく加速した。しかし, 定着化の進度や過程は自治区内 でも地域によって異なる。本論では，1980 年代の改革開放政策以降 に定着化が本格化したものの，現在でもゲルを使用した移動放牧が 行われている地域において，短期間で急変を遂げるモンゴル族の居 住環境について考察する。

\section{1-2. 分析の視点と方法}

これまでに，ゲルの利用実態と用途変化に関して，ゲル利用の盛 んな地域において広域調查を実施した注3)。その結果，多様な移動放 牧の形態が出現しており，ゲル利用の縮小が一様に進んでいるわけ ではないということが確認できたが，年間を通じた移動放牧の形態 と住居の利用実態について詳細が把握できていなかった。そこで本 論では, 調查地の範囲を限定するとともに, 四季を通じての調査事 例を増やし，より詳細な資料収集と分析を加えることを試みる。 まず，調査地の放牧形態の変遷と現状を整理，分類する（第 2 章）。
次に, 調査地でのゲル及びバイシンの所有状況を整理し（第 3 章）, さらに年間を通じた放牧形態と住居の使い分けについて分析し（第4 章)，第 5 章でまとめとする。

\section{1-3. 調査概要}

調查地は，シリンゴル sili yin rool（锡林郭勒）盟・東ウジュムチ ン J̌egün ujuimučin（东乌珠穆沈）旗・ガタブチ qabtabači（嘎达布其）鎮· バインジラガ bayanjilia_aガチャ注4)（白音吉力嘎嘎查）である。シリ ンゴル盟は，自治区全体のなかで，モンゴル族の割合が高いことや 放牧可能な牧草面積が広いことから定着化の進度は遅く, 現在でも ゲルの利用が確認できる地域である。特に東ウジュムチン旗はシリ ンゴル盟で最大の面積を有している（約 4.7 万 $\mathrm{km}^{2}$ ）。人口の約 $72 \%$ を モンゴル族が占めており注5), 農耕化の影響も少ない為, 調査地に選 定した。更に限定した行政区域（ガチャ）については，旗の政府関 係者に依頼し, 調查許可の下りた地域での実施となった注6)。バイン ジラガガチャは，旗の行政公署ウリヤスタイ uliyasutai（乌里雅斯太） 鎮の北方約 $60 \mathrm{~km}$ に位置する (図 1)。モンゴル国との国境に程近く(国 境まで約 $10 \sim 13 \mathrm{~km}), 129$ 世帯の村である。ガチャのなかで, 漢族 の 3 世帯を除きモンゴル族世帯のゲル所有率は $100 \%$, このうち 1 年 に 1 回以上使用している世帯は約半数である。

第一次調查は 2008 年 9 月 $8 \sim 10$ 日，20〜 22 日で，調查地の選定 及び地域概要について政府関係者より情報を得た。調查世帯の紹介 も政府関係者同行のもと行われ，聞き取り及び実測調査を実施した。 第二次調查は 2009 年 2 月 $24 \sim 26$ 日に実施し，冬季のゲルの使い方
* 奈良女子大学大学院人間文化研究科 博士後期課程

** 奈良女子大学大学院人間文化研究科 教授・工博
Graduate Student, Graduate School of Humanities and Sciences, Nara Women's Univ. Prof., Graduate School of Humanities and Sciences, Nara Women’s Univ., Dr. Eng. 
に着目する為,ゲルを利用している世帯に絞って聞き取りを行った。 第三次調查は 2009 年 6 月 $15 \sim 17$ 日で, 夏季の放牧に使用するゲル を中心に聞き取り及び実測調查を実施した。第四次調查は, 2009 年 9 月 $19 \sim 22$ 日で，バイシンを中心とした聞き取り及び実測調查を 実施した。上記 4 度にわたる調查注 7$)$ で, 調查世帯の総数は 36 世帯 である。

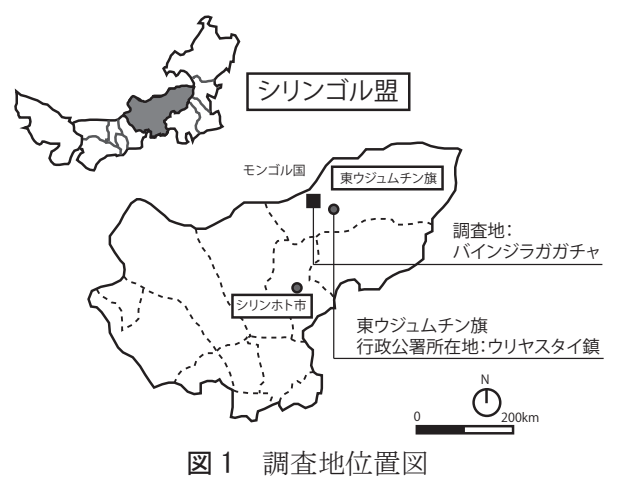

\section{2. 放牧形態の概要とその変化}

ここでは, 聞き取りで得た資料に基づき, 調查地での放牧形態と その変化について記述する。

\section{2-1. 四季移動と牧畜サイクル}

伝統的なモンゴル族の遊牧は, 地域差があるものの, 大まかには春・ 夏・秋・冬という四季によって宿営地を移動する。調查地における 牧畜サイクルは， 2 月末〜 3 月頃にピークを迎える家畜の出産期を 春営地で過ごし, その年産まれた家畜が成長する 5 月下旬から 6 月 初旬頃に夏営地へと移動する。夏営地では主に搾乳と毛を刈る作業 がある。9月頃になると, 冬に備え, 干し草の確保と家畜を太らせ る為のオトル otor と呼ばれる臨時的な移動を繰り返す。11月末頃に は季節風を避けるところなど地形や雪の量, 牧草の様子をみて冬営 地一移動する。初雪が降ってから移動する場所を決めるという世帯 もある。

\section{2-2. 移動放牧の変化}

調查地では 1980 年代以前, 明確な牧地の境界は無く, 牧草と水の 様子をみて頻繁に移動が繰り返されていた。四季の宿営地を拠点と しながらも，1年に 10 回以上，多い場合は 1 ～ 2 日ごとに移動し， 2 週間も同じ場所には留まらなかったという世帯もある。移動距離 も様々で, 各宿営地間は $30 \sim 50 \mathrm{~km}$ ほど, 場合によっては約 $300 \mathrm{~km}$ 離れた場所まで移動することもあった。移動手段は専ら牛車で, 各 世帯 7 〜 10 台ほど保有していた。

人民公社の解体に伴い, 1983 年頃から段階的に家畜が各世帯に分 配された。その際, 牧地についても使用権の分配が始まり, 長距離 移動及び頻繁な移動は減少した注8)。この頃から固定家屋であるバイ シンも少しずつ建築されはじめる。それでもまだ，ゲルを利用して 四季を通じた移動をする世帯は多かった。

その後牧地の測量が厳密となり, 1996 年頃から使用権が 30 年契 約で再分配された。牧地の境界を柵で囲う世帯が増え, 自由な移動 放牧は事実上消滅した。畜舎, さらには住居としてバイシンを建築 する世帯が急増し, 番地も与えられた。これを機に定着化が一気に 加速することとなる。

また, 2003 年からは「退牧還草」政策に伴い「囲封転移戦略」が
展開され始めた注 9)。東ウジュムチン旗では 2008 年時点で, 利用可 能な草原面積のうち約 $78 \%$ で春季休牧, 約 $29 \%$ で区画輪牧, 約 13 \%で禁牧が実施されている。調查地では禁牧世帯はないものの, 毎 年 4 月頃に $20 \sim 30$ 日ほどの期間，限られた範囲内での放牧が義務 付けられ，一部で，区画輪牧が実施されている。これは，畜舎や椢 など固定化拠点の設置が進む要因となっている。

\section{2-3. 現在の放牧方法}

調査地において，各世帯に分配されている牧地面積は，分配時の 世帯人数に比例するが，概补 $7000 \sim 10000$ 畆（mu: 畆 $=666.7 \mathrm{~m}^{2}$ ) 程度が一般的である。区割りは様々だが， 1 辺が $2 \sim 3 \mathrm{~km}$ 程度の規 模である。兄弟でさらに分割し，1世帯あたり 2000 ～ 5000 畆程度 になっていることもある。このなかで井戸，畜舎，住居の固定化拠 点を設ける。また，区画を分けて放牧する「輪牧」の形態が推奨さ れている。但し, 牧地内の区分けは各世帯により異なっており, ど の季節の営地を椢で囲うか, 1 年を何季に分けるかなどは世帯に任 されている。区画を定めておらず，毎年様子をみて使い方を決める という世帯もある。

増加しているのは，借用地である。分配された区域以外にも牧地 を借りて放牧面積を増やしている世帯が，21 世帯確認できた。借用 地を必要とする理由として，以下の 3 つが考えられる。

1 つ目は, 内モンゴル全体で進行している沙漠化の影響で, 牧草 の状態が年々悪化しており, 限られた牧地内では十分な牧草を確保 できないという問題である。その場合, 比較的牧草の状態が良い牧 地を借りて移動する。大半の事例がこの理由によるものである ( 事 例 $1 \cdot 2 \cdot 4 \cdot 5 \cdot 12 \cdot 14 \cdot 15 \cdot 22-25 \cdot 31-35)$ 。毎年決まって牧地を 借りる常時契約と, 牧草の様子から必要な時に借りる臨時契約があ る。

2 つ目は, 牧地の再分配後に婚姻などで増えた世帯が，兄弟・親 戚間でさらに牧地を分配し，輪牧するのに十分な面積を保有してい ない場合である。( 事例 $10 \cdot 11 \cdot 13)$

3 つ目は，牧畜業の経営拡大である。働き手不足や，子どもの就 学等の理由より牧畜業を辞めて都市部へ出た世帯の牧地や家畜を請 負う場合，また分配された牧地だけでは飼うことが難しくなった馬 等の大型家畜を集約して保有するという例もある（事例 $8 \cdot 29)$ 。

牧夫の雇用も増えている。本調査では 10 世帯で雇用が確認できた。 牧夫についても様々な例があり, 人手不足の時にのみ臨時で雇う場 合と，常時放牧を任せる場合がある。

\section{2-4. 放牧形態の分類}

以上より，現在の放牧方法として，固定化拠点を設け，そこから 分配された区域内での短距離移動，あるいは借用地一の中・長距離 移動を行うというパターンが確認できる。また，日帰り放牧をする 場合と，季節営地に放牧拠点を設ける場合がある。

オトルとは家族全体の季節移動とは別に，「一部の者が，一部の家 畜を連れて，一時的に移動する分派的な移動」を表わす言葉として 知られている7)。秋の家畜を太らせるシーズンや, 旱䰠・雪害から 家畜を守る為に行われることが多い。現在調查地では，季節や移動 距離，移動を担う人，移動期間を問わず，畜舎や住居のある固定化 拠点とは別の場所に，放牧拠点となる住居を設ける場合，その放牧 拠点への移動をオトルと呼んでいる。

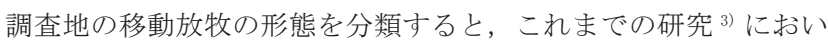


表 1 調查事例の牧畜業に関する基礎情報と住居概要

\begin{tabular}{|c|c|c|c|c|c|c|c|c|c|c|c|c|c|c|c|c|c|c|c|}
\hline \multirow[b]{2}{*}{ 事例 } & \multirow{2}{*}{\begin{tabular}{|l|} 
世帯人 \\
数 (ガ \\
于ャ居 \\
住者)
\end{tabular}} & \multicolumn{3}{|c|}{ 牧地 } & \multirow[b]{2}{*}{$\begin{array}{l}\text { 牧夫の } \\
\text { 雇用 }\end{array}$} & \multirow[b]{2}{*}{$\begin{array}{l}\text { 委託放牧 } \\
\text { の有無 }\end{array}$} & \multicolumn{3}{|c|}{ 家畜の数 単位：頭 } & \multirow[b]{2}{*}{$\begin{array}{l}\text { ゲル } \\
\text { 所有 } \\
\text { 数 }\end{array}$} & \multicolumn{4}{|c|}{ ゲルの用途 } & \multirow[b]{2}{*}{$\mid \begin{array}{c}\text { バイシン建築 } \\
\text { 年 }\end{array}$} & \multicolumn{4}{|c|}{ バイシンの場所（営地） } \\
\hline & & $\begin{array}{l}\text { 牧地面積 } \\
\text { 单位: 畧 }\end{array}$ & 備考 & 借用地 & & & 馬 & 牛 & 羊 山羊 & & $\begin{array}{l}\text { 生活- }- \text { 長期 } \\
\text { 放牧 }\end{array}$ & $\begin{array}{c}\text { 短期放 } \\
\text { 牧 }\end{array}$ & 行事 & $\begin{array}{l}\text { 牧夫が } \\
\text { 使用 }\end{array}$ & & 冬 & 春 & 夏 & 秋 \\
\hline 1 & $6(6)$ & 6950 & & 臨時 & 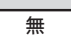 & $\begin{array}{c}\text { 無 } \\
\end{array}$ & 2 & 30 & 300 & 1 & & $\bar{\Delta}$ & $\bullet$ & & 2007 & & & " & \\
\hline 2 & $5(4)$ & 5000 & & 臨時 & $\begin{array}{ll}\text { 無 } \\
\end{array}$ & 無 & - & - & - & 1 & & - & - & & 2000 & & a & & \\
\hline 3 & $3(3)$ & 9000 & & $\begin{array}{l}\text { 無 } \\
\end{array}$ & $\begin{array}{ll}\text { 無 } \\
\end{array}$ & 無 & 10 & - & - & 1 & & & - & & 2008 & & 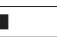 & & \\
\hline 4 & $4(2)$ & 9000 & & 臨時 & 常時 & 無 & 10 以上 & 30 & 500 & 1 & & - & $\bullet$ & - & $1986 \rightarrow 1992$ & & & - & \\
\hline 5 & $5(2)$ & 8000 & & 臨時 & 臨時 & 無 & 数頭 & 20 以上 & - & 1 & - & $\Delta$ & - & & 2001 & & 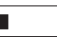 & & \\
\hline 6 & $6(3)$ & - & & $\begin{array}{l}\text { 無 } \\
\end{array}$ & $\begin{array}{ll}\text { 無 } \\
\end{array}$ & 無 & - & - & - & 2 & & $\bullet$ & $\bullet$ & & 1998 & & 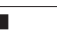 & & \\
\hline 7 & $4(4)$ & - & & 無 & 無 & 無 & 数頭 & 5 & - & 1 & & (2) & & & 1990 & & 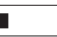 & & \\
\hline 8 & $7(5)$ & 8000 & $\begin{array}{c}\text { 借用地 } \\
4000 \text { 含む }\end{array}$ & 常時 & 無 & 無 & 3 & 60 & 800 & 1 & & - & - & & 1999 & & & & \\
\hline 9 & $5(3)$ & 10000 & & $\begin{array}{ll}\text { 無 } \\
\end{array}$ & $\begin{array}{l}\text { 無 } \\
\end{array}$ & $\begin{array}{l}\text { 無 } \\
\end{array}$ & 数頭 & 0 & 600 & 1 & & $\bullet$ & $\bullet$ & & $1990 / 1999$ & & & - & \\
\hline 10 & $4(3)$ & 5000 & & 常時 & 無 & 無 & 3 & 30 & 200 & 1 & & $\bullet$ & $\bullet$ & & 2003 & & - & & \\
\hline 11 & $4(3)$ & 5000 & & 常時 & 無 & 無 & 2 & 10 & 300 & 1 & & $\bullet$ & $\bullet$ & & 2007 & & - & & \\
\hline 12 & $4(3)$ & 9000 & $\begin{array}{c}\begin{array}{c}\text { 借用地 } \\
3000 \text { 含む }\end{array} \\
\end{array}$ & 常時 & 無 & $\begin{array}{l}\text { 無 } \\
\end{array}$ & 2 & 0 & 500 & 1 & & • & - & & 2004 & - & - & - & - \\
\hline 13 & $4(4)$ & 2000 & & 常時 & $\begin{array}{l}\text { 無 } \\
\end{array}$ & 無 & 0 & 0 & 300 & 1 & & - & - & & 2004 & & & - & \\
\hline 14 & $4(4)$ & 8635 & & 常時 & 臨時 & 無 & 0 & 14 & 200 以上 & 1 & & $\bullet$ & $\bullet$ & & 1999 & & & a & \\
\hline 15 & $4(4)$ & 10000 & & 常時 & $\begin{array}{l}\text { 無 } \\
\end{array}$ & 無 & 0 & 0 & 600 & 2 & $\bullet$ & & $\bullet$ & & 1999 & & - & & \\
\hline 16 & $7(4)$ & 9500 & & 無 & 無 & 無 & 0 & 0 & 500 & 1 & $\bullet$ & & $\bullet$ & & 1980 年代 & & - & & \\
\hline 17 & $7(4)$ & 17000 & & 無 & $\begin{array}{l}\text { 無 } \\
\end{array}$ & 無 & 0 & 17 & 400 & 2 & $\bullet$ & - & - & & 2000 & & - & & \\
\hline 18 & 2(2) & 7565 & & 無 & 臨時 & 無 & 0 & 数 10 頭 & \begin{tabular}{l|l|}
60 & 0 \\
\end{tabular} & 1 & & $\bullet$ & $\bullet$ & & 1987 & & a & & \\
\hline 19 & $5(2)$ & - & & 無 & 無 & $\begin{array}{l}\text { 無 } \\
\end{array}$ & - & - & - & 1 & $\bullet$ & $\Delta$ & $\bullet$ & & 2006 (畜舎） & & 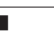 & & \\
\hline 20 & $5(2)$ & 10000 & & 無 & 臨時 & 無 & - & - & - & 2 & & (2) & $\bullet$ & & $1998 \rightarrow 2005$ & a & & & \\
\hline 21 & $4(2)$ & 7500 & & $\begin{array}{lll}\text { 無 } \\
\end{array}$ & 常時 & 無 & 数頭 & 数 10 頭 & 1000 & 2 & & (-) & $\bullet$ & (-) & $1994 / 1998$ & & & & \\
\hline 22 & $4(1)$ & 10000 & & 常時 & 常時 & 無 & 数頭 & 20 & 600 & 2 & & (2) & $\bullet$ & (-) & 1994 & & & " & \\
\hline 23 & $4(2)$ & 8900 & & 常時 & 無 & 無 & 2 & 20 & 600 以上 & 1 & & (-) & & & - & & 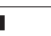 & & \\
\hline 24 & $3(2)$ & - & & 常時 & 無 & 無 & - & - & - & 1 & & $\bullet$ & & & - & & n & & \\
\hline 25 & $3(2)$ & 14000 & $\begin{array}{c}\begin{array}{c}\text { 借用地 } \\
5700 \text { 含む }\end{array}\end{array}$ & 常時 & 無 & 無 & 10 数頭 & 30 & 600 & 1 & () & & & & 1998 & & - & & \\
\hline 26 & $3(3)$ & - & & - & 無 & 無 & 5 & 20 & 500 以上 & 1 & & $\bullet$ & & & 2006 & & 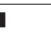 & & \\
\hline 27 & 2(2) & 10000 & $\begin{array}{l}\text { 兄弟3人 } \\
\text { 分 }\end{array}$ & 無 & 無 & 無 & 0 & 0 & 200 & 1 & () & & & & 1991 & & I & & \\
\hline 28 & $4(1)$ & 10000 & $\begin{array}{l}\text { 兄弟3人 } \\
\text { 分 }\end{array}$ & 無 & 無 & 無 & 10 & 0 & 500 & 1 & & () & & & 1999 & & - & & \\
\hline 29 & $5(3)$ & 13000 & & 臨時 & $\begin{array}{ll}\text { 無 } \\
\end{array}$ & 有 & 100 & 20 & 1000 & 2 & & (0) & $\bullet$ & & 2001 & & & E & \\
\hline 30 & $5(3)$ & 9900 & & 無 & 無 & 無 & 2 & 34 & 500 & 2 & & (2) & $\bullet$ & & $2000 \rightarrow 2007$ & & - & & \\
\hline 31 & $2(2)$ & 9066 & & 常時 & 無 & 無 & 0 & 42 & 350 & 1 & & $\bullet$ & $\bullet$ & & $1991 \rightarrow 2005$ & & & - & \\
\hline 32 & $4(2)$ & 10000 & & 臨時 & 無 & 無 & 0 & 90 & 400 & 1 & & $\bullet$ & $\bullet$ & & $1993 \rightarrow 2000$ & - & - & - & - \\
\hline 33 & $3(2)$ & 14000 & $\begin{array}{l}\text { 兄弟2人 } \\
\text { 分 }\end{array}$ & 常時 & 無 & 無 & 4 & 20 & 400 & 2 & $\bullet$ & & $\bullet$ & & 2009 & & & & \\
\hline 34 & $4(2)$ & 9000 & & 常時 & 常時 & 有 & 10 & 23 & 400 & 2 & & & $\bullet$ & (0) & 1996 & & & & \\
\hline 35 & $4(3)$ & 12000 & & 臨時 & 常時 & 無 & 20 & 15 & 500 & 2 & & & $\bullet$ & (-) & $1982 \rightarrow 2000$ & & E & & \\
\hline 36 & $3(2)$ & 8000 & & $\begin{array}{l}\text { 無 } \\
\end{array}$ & 臨時 & 無 & 2 & 0 & 500 以上 & 1 & & (2) & & (-) & 2003 & & & - & \\
\hline
\end{tabular}

木製ゲル ○：鉄製ゲル

山：簡易ゲル

ロ : バイシンの位置 一: 不明

て, 家畜群の移動の有無 (オトルの有無), 家畜所有主の移動の有無, 放牧の担い手に基づいて分類したタイプ $\mathrm{A} \sim \mathrm{E}$ に加え，放牧拠点の 場所（移動先）についても家畜所有主の牧地内（ I ）か借用地（III） か, あるいはいずれにも構えるか（II ）という点に着目する。A I 〜 E III までの分類について調查事例を当てはめると表 2 のようにな る。タイプEに属し, オトルは実施せず日帰り放牧のみという事例 も 3 事例あるが, 多くが必要に応じてオトルを実施しており, 家畜 所有主の移動を伴うオトルが半数以上を占めている。

ここで，特筆すべきはタイプDである。家畜を別の牧畜民に委託 する場合, 既往文献ではその委託先の牧畜民が配分を受けている牧 地において放牧が実施される例が示されている ${ }^{8}$ 。調查地ではその ような例に加え, 放牧拠点の場所についてはさらに複合的な事例が みられる。家畜所有主に配分されている牧地, あるいは借用地を合 わせた場所で, 家畜を別の牧畜民に委託するという事例である（事 例 29 ・34)。委託先の牧畜民は親族や近隣住民であることが多く, その場合は放牧場所が委託先牧畜民の配分された牧地も含めて広が る。これは, シリンゴル盟の他地域でも確認されている方法 ${ }^{3)}$ で, 牧地と労働力を相互に有効利用しており, 労働力不足や草原の悪化 等への一つの対応策である。
表 2 移動放牧の形態

\begin{tabular}{|c|c|c|c|c|c|c|}
\hline \multirow{3}{*}{$\begin{array}{l}\text { 家畜群の } \\
\text { 移動 }\end{array}$} & \multirow{3}{*}{$\begin{array}{c}\text { 家畜 } \\
\text { 所有主の } \\
\text { 移動 }\end{array}$} & \multirow{3}{*}{ 放牧の担い手 } & \multirow{3}{*}{$\begin{array}{l}\text { タ } \\
\text { プ }\end{array}$} & \multicolumn{3}{|c|}{ 放牧拠点の場所 } \\
\hline & & & & $\begin{array}{c}\text { 家畜所有主の } \\
\text { 牧地内 }\end{array}$ & 両方 & 借用地 \\
\hline & & & & I & II & III \\
\hline \multirow{8}{*}{ 有 } & \multirow{4}{*}{ 有 } & 家族 & & A I & $\mathrm{A}$ II & AIII \\
\hline & & （世帯全員） & A & $\begin{array}{lllll}6 & 7 & 9 & 16 & 17 \\
19 & 26 & 27 & 30\end{array}$ & 15 & 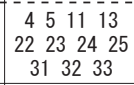 \\
\hline & & \multirow{2}{*}{$\begin{array}{c}\text { 家族 } \\
\text { (世帯の一部) }\end{array}$} & \multirow{2}{*}{ B } & B I & B II & BIII \\
\hline & & & & $192128 \quad 36$ & 12829 & $\begin{array}{c}1213 \quad 14 \\
2032\end{array}$ \\
\hline & \multirow{6}{*}{ 無 } & \multirow{2}{*}{ 牧夫を雇用 } & \multirow{2}{*}{ C } & C I & C II & CIII \\
\hline & & & & 2136 & 34 & $\begin{array}{lllll}4 & 5 & 20 & 22 & 35\end{array}$ \\
\hline & & \multirow{2}{*}{$\begin{array}{c}\text { 別の牧畜民に } \\
\text { 委託 }\end{array}$} & \multirow{2}{*}{ D } & D I & DII & DIII \\
\hline & & & & - & 2934 & - \\
\hline \multirow{2}{*}{ 無 } & & \multirow{2}{*}{-} & \multirow{2}{*}{$E$} & E I & $\mathrm{E}$ II & EIII \\
\hline & & & & 318 & 10 & - \\
\hline
\end{tabular}

\section{3. 住居の所有状況と使用事例}

ここでは, 調查地における住居の所有状況を整理し, 主にゲルの 使用事例を紹介する（図 2)。 


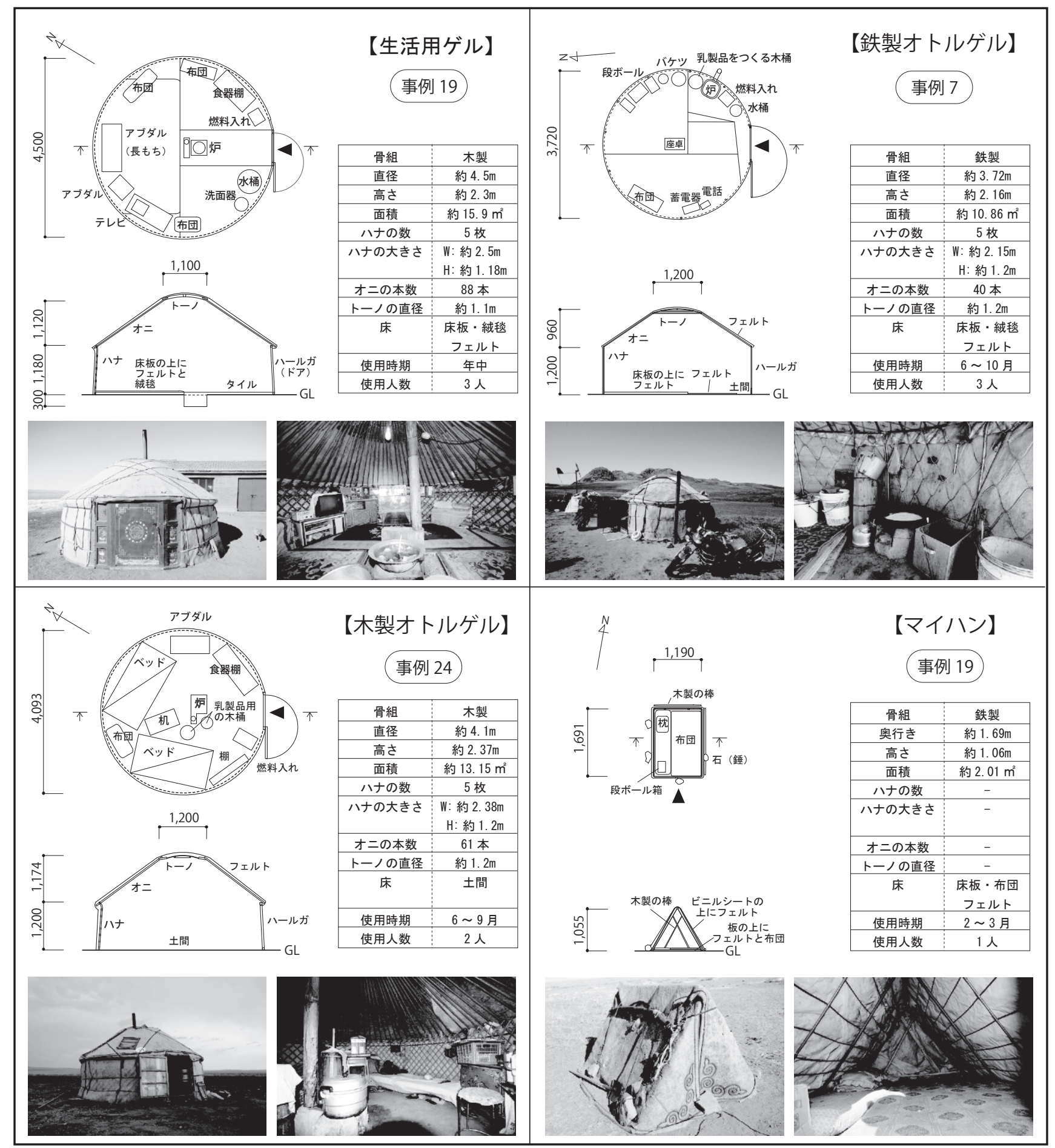

図 2 ゲル及びマイハンの概要

\section{3-1. ゲルとバイシンの所有状況}

調查事例では全世帯がゲルを所有している。その用途は主に放牧 （オトル）であるが, 長期（半年以上）あるいは短期（半年未満）の

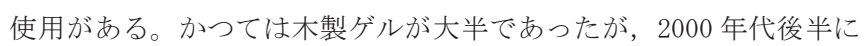
入り，鉄製ゲルが急速に普及している。この鉄製ゲルは，定着化の なかで，世帯全員ではなく一部の臨時的な移動の際に使用するオト ル用の簡易ゲルとして増加し始めた。

調查世帯で現在使用されているゲルは，す心゙てウリヤスタイ鎮の ゲル専門店より購入したものである。シリンゴル盟で流通している
ゲルの多くは工場で生産されており, 各地に注文を請負う店が存在 する。ここで大きさや色彩等を指定してオーダーメイドする。2000 年代に入ると, 鉄製ゲルの販売が始まった。各地の小売店で簡単な 溶接が可能で，直接購入できる。 30 年ほど前までは牧畜民の自家製 のゲルや家具, 構造材を覆うフェルト, 紐などの小物がみられた。 調查事例のなかには，伝統的な家具等の製作技術が引き継がれてい る家系もあったが (事例 4 ・32), 現在は工場生産されたものが主流 である。

1 世帯で 2 つのゲルを所有し，1つはオトル用，1つは行事用と， 
用途によって専用にしている事例も多い。その場合，オトルには鉄 製あるいは古い木製のもの, 行事には木製ゲルを使用する。祭事の 際には当番の世帯がゲルを建て, 客人をもてなす。調查地では伝統 行事が頻繁に行われており, そこで見栄えの良い伝統的な木製ゲル を用意できるよう新調する事例（事例 30）や，普段の放牧には使用

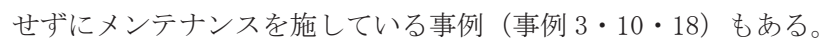

バイシンについては, 1990 年前後から導入が始まり, 現在ではほ ぼ $100 \%$ が固定化拠点にバイシンを建築している。大工は主に家畜 の売買の為に当該地域を行き来する漢族の紹介によって決まること が多い。ウリヤスタイ鎮に限らず, 他地方から営業に来る大工もいる。

\section{3-2. 使用されているゲルの事例と特徴}

ここでは，調查地で実際に使用されていたゲル及び簡易テント注 10) の概要と特徵を事例とともに示す。

\section{1）生活用（長期オトル）のゲル}

事例 19 では，2006 年，固定化拠点に畜舎を建築したが，居住用 のバイシンは所有しておらず，実質一年中ゲルで生活している。20 年以上前, 夫妻が結婚した際に譲り受け, 家族 5 人で使用していた。 現在は娘 2 人が独立し, 3 人で住んでいる。中央に炉を配し, 周り には 3 枚の床板, フェルト, 絨廹を重ねている。5 枚の壁材 (ハナ) を使用しており，この地域では一般的な規模のゲルである。

\section{2）鉄製オトルゲル}

鉄製ゲルは 14 世帯が所有しているが，いずれも 2000 年以降，大 半が 2005 年以降に購入している。700〜 1000 元（1元 $\fallingdotseq 15$ 円）程 度で手に入り，安価であること（木製ゲルの場合 $5000 １ 2000$ 元程 度)，移動に自動車を使う世帯が増えたことが普及に繋がっている。 また，牧夫を雇用する場合，鉄製ゲルを牧夫の住まいとすることが 多い。

事例 7 は夏の間オトルで鉄製ゲルを利用する。2007 年までは自家 製の木製ゲルを使用していたが, 古くなり強風で破損した為, 新た に購入した。八ナは 5 枚あるが，木製ゲルよりも小規模である。面 積が小さい為, 炉を入口付近に寄せ 2 枚の床板を張っている。夏の 間は, 暑さをしのぐ為, 炉を入口付近へ寄せ，煙突も屋外から突き 出るようにしている。

\section{3）木製オトルゲル}

基本的には生活用ゲルと同じ構造になるが，オトルが短期間，あ るいは放牧者が少人数である場合, 床を張らずに土間のままという ゲルがみられる。事例 24 では, 近隣世帯の牧地を借りて委託放牧を 請け負っており，ゲルは牧地所有主のものを借りている。床板は張 らずに, ベッドで代用している。夏のオトルなので寒さも問題ない。 大きな家具は寸べて近くにある牧地所有主の家から運んだ。牧地の 賃借と同時にゲルの賃借も生じている。

\section{4）簡易テント}

マイハン maihan はかつて四季の宿営地から家畜を切り離して臨時 に行うオトルで用いられていた断面が三角形になる簡易なテントで ある。現在このようなオトル自体が少なくなったが，事例 19 では， 生活拠点であるゲルから, さらに臨時オトルを行う際に使用寸る。 家畜の出産シーズンに，仔羊をゲルのある生活拠点からわずか $100 \mathrm{~m}$ 程離れた場所に移動させ，この家畜を守る為夜になると家族のうち 1 人が交代で番をする。マイナス 40 度を下回ることのある冬に暖房 設備のないマイハンであるが，狭い空間でフェルト，毛布を重祆る
と暖がとれる。骨組は家畜囲いの鉄柵，そのうえにビニルシートと ゲルに使うフェルトを重敉，飛ばないように石でおさえている。

他にも，聞き取りによると，壁材の八ナの部分を使わずに，屋根 材の才二をそのまま地面に建てたもの注11)（事例 1・5）や，3つの八 ナで小さな円をつくり，屋根材のオニは使わず，そのままフェルト をかぶせるといった事例もみられる（事例 1)。

\section{4. 年間を通じたゲルとバイシンの利用実態}

表 3 では, 各事例のオトルの時期と, 年間を通じて使用している 住居を示している。各事例の列で上段が放牧拠点で使用する住居, 下段が固定化拠点で使用する住居である。

\section{4-1． 放牧拠点で使用する住居}

まず，放牧拠点で使用する住居に着目すると，ゲルが大半を占め ており，簡易テントとバイシンの使用が数事例みられる。使用時期 は数か月から一年中まで様々であるが，6か月を超える長期に渡っ てゲルを用いてオトルを実施する世帯が 12 世帯, そのうち 8 世帯で 家畜所有主の家族全員がゲルに居住している（表 3)。

さらに，冬季から春季に至るまでオトルでゲルを使用している世 帯が 21 世帯あり，このうち家畜所有主の家族が使用しているのは 18 世帯である。これには，以下の理由が考えられる。

1 つ目は, 固定化拠点の位置である。防寒目的や家畜の出産シー ズンに合わせて冬・春営地に畜舎と住居を設置する事例が多いなか (春営地にバイシンを建築しているものが 12 世帯, 冬営地が 1 世帯, 冬・春を一つの営地としてそこに建築しているものが 10 世帯)，一 方で, 夏営地にバイシンを建築している事例も 9 世帯ある（表 1・3）。 これは，バイシンを建築する際，井戸の位置を重要視している為で ある。牧地の分配によって，それまで共用であった井戸を各自の区 域内で設けることが必要となった。井戸が設置できる場所は地形等 の制約がある為, 固定化拠点の位置決定において重要な要素となる。 地形条件や金銭的な問題で井戸を複数設置できない場合などは限ら れた井戸の傍に固定化拠点を設け, 夏営地と寸る。冬営地では積雪 を利用すると，井戸がなくても放牧が可能である。

2 つ目は, 第 2 章で述べたように, 冬営地として借用地を利用寸 る事例が多いことである。冬季に牧草の状態が良いところや比較的 暖かい場所を探してオトルを実施する。

放牧拠点でバイシンを使用している事例 9 ・ 20 ・ 36 では，分配さ れた牧地内を区切る輪牧方式を採用しており, 夏・冬の営地をはっ きりと分けている。毎年ほぼ定まった場所で放牧する為, ゲルの代 わりに小規模なバイシンを建てている。

\section{4-2. 固定化拠点で使用する住居}

固定化拠点の住居は概ねバイシンであるが，事例 $17 \cdot 22 ・ 36$ でゲ ルとの併用がみられる。事例 17 は冬・春営地にバイシンを新築した が，主人の部屋としてゲルを併設し，夏・秋営地へ行くときにはそ のゲルに家族全員が住む。事例 22 は，バイシンの塀で囲われた庭 の中にゲルを建てている。これは，牧夫が自ら持参したものである。 家畜所有主である主人はバイシンに住んでいるが，食事などは共同 で生活をしている。冬営地一行くときには主人もゲルを持って, 2 つのゲルを放牧拠点に建てる。事例 36 の固定化拠点のゲルは, 倉庫 として使用しているものである。冬営地へ行く時には, そのゲルを 牧夫の住居とし，主人はバイシンを使用する。 
表 3 調査事例の放牧サイクルと住居の使い分け

\begin{tabular}{|c|c|c|c|c|c|c|c|c|c|c|c|c|c|c|c|c|}
\hline \multirow[t]{2}{*}{ 事例 } & \multicolumn{12}{|c|}{ 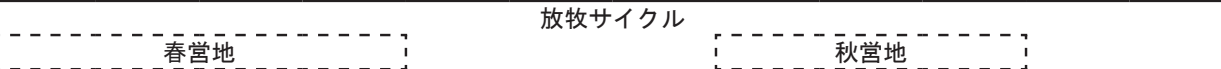 } & \multirow{2}{*}{$\begin{array}{c}\text { オトル } \\
\text { の期間 } \\
\text { 半年 } \\
\text { 以上 }\end{array}$} & \multirow[t]{2}{*}{$\begin{array}{l}\text { 春 - 冬 } \\
\text { に } \\
\text { オトル }\end{array}$} & \multirow[t]{2}{*}{\begin{tabular}{|c|} 
夏営地 \\
にバイ \\
シン
\end{tabular}} & \multirow[t]{2}{*}{$\begin{array}{c}\text { 移動放牧の } \\
\text { 形態 }\end{array}$} \\
\hline & 2月 & 3月 & 4月 & 5月 & 6月 & 7月 & 8月 & 9月 & 10月 & 11月 & 12月 & 1月 & & & & \\
\hline 1 & 口 & ! & a & a & a & a & घ & a & 口 & $\underline{\Delta}$ & $\Delta$ & $\Delta$ & & $\checkmark$ & $\checkmark$ & B II \\
\hline 2 & 口 & ㅁ & ㅁ & ㅁ & $\because$ & 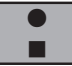 & ㅁ & ! & ㅁ & a & a & 口 & & & & B II \\
\hline 3 & 口 & ㅁ & 口 & 口 & ㅁ & ㅁ & ㅁ & 口 & ㅁ & 口 & ㅁ & 口 & & & & E I \\
\hline 4 & $*$ & $*$ & $*$ & $*$ & $*$ & $*$ & $*$ & $*$ & $*$ & $*$ & $*$ & $*$ & & & $\checkmark$ & A III $\cdot$ C III \\
\hline 5 & $\bullet$ & 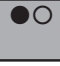 & 0 & $\infty$ & - & - & 口 & $\square$ & 口 & 0 & 0 & 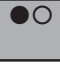 & $v$ & $\checkmark$ & & A III $\cdot C$ III \\
\hline 6 & 口 & ! & 口 & 口 & $\bullet$ & $\bullet$ & $\bullet$ & $\bullet$ & - & 口 & 口 & 口 & & & & A I \\
\hline 7 & घ & घ & 口 & घ & $\bullet$ & $\bullet$ & $\bullet$ & $\bullet$ & $\bullet$ & - & - & 口 & & & & A I \\
\hline 8 & $\because$ & ! & 口 & घ & $\because$ & $\because$ & $\because$ & $\because$ & $\because$ & $\because$ & 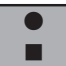 & 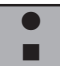 & $\checkmark$ & $\checkmark$ & & B II \\
\hline 9 & - & - & - & 口 & - & - & ㅁ & - & OI & II & OI & OI & & $\checkmark$ & $\checkmark$ & A I \\
\hline 10 & घ & - & 口 & 口 & 口 & - & 口 & 口 & 口 & घ & घ & घ & & & & E II \\
\hline 11 & $\bullet$ & $\bullet$ & 口 & घ & घ & घ & घ & $\square$ & घ & - & - & - & & $\checkmark$ & & A III \\
\hline 12 & $\because$ & a & a & a & $\square$ & घ & a & a & घ & a & $\because$ & $\div$ & & $\checkmark$ & & B III \\
\hline 13 & $\bullet$ & 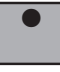 & 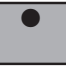 & 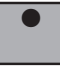 & ㅁ & 므 & ㅁ & ㅁ & ㅁ & 모 & ㅁ & ㅁ & & $\checkmark$ & $\checkmark$ & A III $\cdot$ B III \\
\hline 14 & * & * & $*$ & $*$ & $*$ & * & $*$ & $*$ & $*$ & $*$ & * & $*$ & & & $V$ & B III \\
\hline 15 & घ & - & $\bullet$ & $\bullet$ & 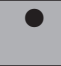 & [ & [ & 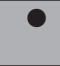 & $\bullet$ & $\bullet$ & 口 & 口 & $\checkmark$ & $\checkmark$ & & A II \\
\hline 16 & 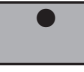 & $\bullet$ & $\bullet$ & ㅁ & - & ㅁ & ㅁ & ㅁ & - & 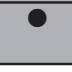 & - & - & $\checkmark$ & $\checkmark$ & & A I \\
\hline 17 & घ0 & 우 & $\bullet$ & 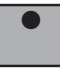 & - & - & - & - & 을 & 0 & घ0 & घ0 & $\checkmark$ & $\checkmark$ & & A I \\
\hline 18 & $\mathbf{\square}$ & $\mathbf{a}$ & 口 & $\square$ & - & ㅁ & 口 & 口 & $\square$ & $\mathbf{a}$ & घ & घ & & & & E I \\
\hline 19 & $\hat{0}$ & $\hat{0}$ & $\bullet$ & $\bullet$ & • & - & • & $\bullet$ & $\bullet$ & $\bullet$ & • & 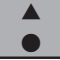 & $\checkmark$ & $\checkmark$ & & $A I \cdot B I$ \\
\hline 20 & 口 & $\square$ & 口 & $\square$ & $\square$ & Oت & OE & On & Oت & OE & 口 & घ & & & & B III $\cdot$ C III \\
\hline 21 & 0 & O & O & O & O & O & 0 & 0 & $\begin{array}{l}00 \\
\square\end{array}$ & $\begin{array}{c}0 \bullet \\
\square\end{array}$ & 0 & 0 & $\checkmark$ & $\checkmark$ & & $B I \cdot C I$ \\
\hline 22 & 0 & $=0$ & - 0 & $=0$ & 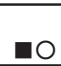 & 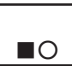 & - & 0 & 00 & 0 & 0 & 00 & & $\checkmark$ & $\checkmark$ & A III $\cdot$ C III \\
\hline 23 & $\bullet$ & - & ㅁ & 口 & - & - & 口 & - & $\bullet$ & - & - & - & & $\checkmark$ & & A III \\
\hline 24 & - & $\mathbf{\square}$ & - & 口 & - & 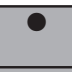 & 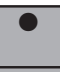 & - & ㅁ & ! & घ & - & & & & A III \\
\hline 25 & $\overline{0}$ & a & 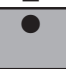 & $\overline{0}$ & - & - & $\bullet$ & $\bullet$ & - & - & - & - & $\checkmark$ & $\checkmark$ & & A III \\
\hline 26 & 口 & घ & a & घ & घ & घ & a & घ & 口 & $\bullet$ & $\bullet$ & $\bullet$ & & $\checkmark$ & & A I \\
\hline 27 & 口 & 口 & - & - & - & - & 0 & 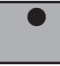 & 0 & घ & 口 & 口 & $\checkmark$ & & & A I \\
\hline 28 & $*$ & $*$ & $*$ & $*$ & * & $*$ & * & * & * & $*$ & * & * & & & & B I \\
\hline 29 & $*$ & $*$ & $*$ & $*$ & $*$ & $*$ & $*$ & $*$ & * & $*$ & $*$ & $*$ & & & $v$ & B II $\cdot$ D II \\
\hline 30 & 0 & 口 & a & a & a & ㅁ & ㅁ & 口 & 口 & 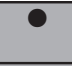 & 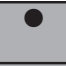 & 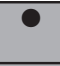 & & $\checkmark$ & & A I \\
\hline 31 & 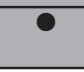 & $\overline{0}$ & घ & $\square$ & $\square$ & $\square$ & $\square$ & ㅁ & $\square$ & $\bullet$ & - & $\bullet$ & & $\checkmark$ & $\checkmark$ & A III \\
\hline 32 & $*$ & $*$ & $*$ & $*$ & $*$ & $*$ & $*$ & $*$ & $*$ & $*$ & $*$ & $*$ & & & & A III $\cdot$ B III \\
\hline 33 & [ & a & a & - & $\bullet$ & - & • & - & - & - & - & - & $\checkmark$ & $\checkmark$ & & A III \\
\hline 34 & घ & a & a & O & O & O & O & O & O & $\square$ & a & a & $\checkmark$ & & & C II $\cdot \mathrm{D} I$ \\
\hline 35 & $\square$ & 0 & O & 0 & 0 & 0 & 0 & 0 & 0 & O & 0 & O & $\checkmark$ & $\checkmark$ & & C III \\
\hline 36 & $\begin{array}{l}O \square \\
\end{array}$ & घ0 & 0 & E0 & 10 & घ0 & 口0 & E0 & 口0 & On & On & OI & & $\checkmark$ & $\checkmark$ & $B$ I $\cdot C I$ \\
\hline
\end{tabular}

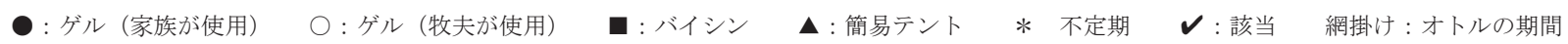
移動放牧の形態は表 2 参照（放牧の担い手が A : 世帯全員 B : 世帯の一部 C : 牧夫 D : 別の牧畜民に委託

放牧拠点が I : 家畜所有主の土地内 IIII：借用地 III：両方) 


\section{5. おわりに}

\section{5-1. まとめ}

牧畜民の定着化に伴う居住環境の変化を考察すると，まず，移動 放牧の形態分析より明らかとなった牧地の利用変化がある。また, その変化が年間を通じたゲルとバイシンの使い分けに大きく影響し ていることが明らかとなった。これを以下にまとめる。

1）共有地において季節を通じて頻繁に移動が繰り返されていた調査 地では，1980 年代の人民公社解体後，家畜の分配，1990 年代の牧地 使用権の再分配, 2000 年代の退牧還草政策等を経て, 各世帯の牧地 境界を明確に区分するようになった。その為, 各世帯が放牧で利用 できる牧地の範囲は数十〜数百 $\mathrm{km}$ 単位から, 数 $\mathrm{km}$ 単位へと縮小して いる。これに伴い，固定化拠点やバイシンの設置が急速に進み，バ イシン普及率は約 100\%となっている。

2）牧地の使用権分配によって移動が制限された結果生じる問題とし て, 牧草の維持と確保, 分配後の人口増加, 水源確保などがある。 限られた牧地の中では, 気候や地形条件, 人口や家畜の過密等によ る牧草の悪化へ対応寸ることが難しい。そこで, 分配された牧地内 においても井戸の位置や積雪, 四季による牧草の状況を考慮した牧 地の細分化，あるいは借用地を利用して放牧範囲の拡大を図る事例 が多くみられる。このような対応が固定化拠点の位置選定に影響し, またバイシンが普及しているにも関わらず，短期から長期に渡るゲ ルの利用が盛んな要因となっている。

3）ゲルの利用状況をみると, 移動距離の縮小やバイシンの普及によ る使用期間の短期化，牧夫や単身での使用，鉄製ゲルの普及など， 臨時的で簡易な仮住まいとして利用される傾向にある。一方で，上 述 2）の理由などにより，冬季や長期間の移動を行う場合もある。 行事にも伝統的で格式の高い従来の木製ゲルが利用されることが多 い。当該地域においては定着化に伴いゲル利用の縮小・簡易化傾向 と伝統的ゲルの保有・活用傾向が同時に確認できる。

\section{5-2. 今後の課題}

本論では，年間を通じたゲルとバイシンの利用実態をみるなかで， 定着化の象徵でもあるバイシンの具体的な利用状況については触れ ていない。他地域と比較しても短期間でゲルからバイシンへの移行 がみられるこの調查地で，牧畜民の居住環境がじのように変化して いるのか，バイシンの間取り変化等も含めて次報にて分析する。

本研究は, 財団法人 住宅総合研究財団の助成を受け実施した「中 国内モンゴル自治区東ウジュムチンにおけるゲルの調査（代表 : 中 山徹)」による研究成果の一部である。

\section{謝辞}

本調查は, 内蒙古大学蒙古学学院のバヤモンド学院長, 内蒙古婦 女幹部学校オドンゲレル副教授をはじめとする現地コーディネータ 一の方々には多大なる御協力を頂いた。また, 奈良女子大学文学部 武藤康弘准教授, 同生活環境学部山本直彦准教授, 同大学院博士前 期課程（当時）芦田奈緒さん, 東京外国語大学谷弘萌さんには, 現 地調查において御協力頂いた。ここに記し，感謝の意を表したい。

\section{参考文献}

1）松川節：移動と定住のはざまで, 佐藤浩司編 : 住まいつむぐ, 学芸出版社, p196，補注 2 より, 1998
2) 包慕萍：モンゴルにおける都市建築史研究一遊牧と定住の重層都市フフホ 卜，東方書店，p. 39，2005

3）野村理恵・中山徹・今井範子・室﨑生子・婭茹・咏梅 : 定住生活における 移動住居ゲルの利用実態と用途変化一中国・内モンゴル自治区シリンゴル盟 の牧畜民を事例として一，日本建築学会計画系論文集，第 73 巻，第 630 号, pp. $1735-1742,2008.8$

4）东乌珠穆沁旗志编委会编：东乌珠穆沁旗志（上), 内蒙古人民出版社， 2001

5）锡林郭勒盟志编纂委员会编：锡林郭勒盟志, 内蒙古人民出版社, 1996

6）齐伯益 主编：锡林郭勒盟畜牧志，内蒙古人民出版社，2002

7）小長谷有紀：モンゴル草原の生活世界，朝日新聞社，1996

8）小長谷有紀 : 定住化過程におけるモンゴル族の牧畜経営—シリンホト市内 の事例から，現代中国の民族と経済，世界思想社, 2001

9）シンジルト：中国西部辺境と「生態移民」，小長谷有紀・シンジルト・中尾 正義：中国の環境政策 生態移民, 昭和堂, p. 14, 2005

10）スエー：「生態移民」による新たな草原開拓一内モンゴル自治区シリンゴ ル盟鑲黄旗における牧畜民の事例から一，小長谷有紀・シンジルト・中尾正 義：中国の環境政策 生態移民，昭和堂，p. 78，2005

\section{注}

注 1）モンゴル語のゲルは家屋一般を指す普通名詞，また部屋を表わす言葉と しても用いられる ${ }^{1)}$ 。しかし，狭義には移動式天幕住居を指し固定式家屋バ イシンとは区別される。本稿では, 移動式天幕住居を指す言葉として用いる。 注 2）バイシンはモンゴル語で「土や煉瓦，木や石で建てられた動かない家， あるいはとがった屋根を持つ家」といら意味である ${ }^{2)}$ 。漢語では「板升」と 表記するが，語源については漢語・モンゴル語双方の説がある。本稿では， 日干し煉瓦造や煉瓦造の固定家屋について「バイシン」と表記する。

注 3）平成 18 （2006）年度科学研究費補助金（基盤研究 A，代表：今井範子, 課題名「中国内モンゴル自治区におけるモンゴル民族の生活様態と居住空間 に関する総合的研究」）による調査で，結果は参考文献 3）にまとめた。

注 4）「盟」とは地級行政区に相当し，モンゴル語ではアイマグ aimar と呼ぶ。 盟と同レベルの行政区として「市 (盟級市)」がある。「旗」は県級行政区に 相当し，モンゴル語でホショーxosizu と呼ぶ。「鎮」はモンゴル語でバラガ ス balgasu と呼ぶ。郷に相当する行政区で，同レベルには「ソムsumu」があ る。「ガチャ $\gamma_{\text {ača }} a 」$ は村に相当する。

注 5) 1949 年以前，商人や資源開発労働者等の流動人口を除くと，漢族の定住 者はいなかったとされている ${ }^{4)}$ 。その後徐々に増加しているが, 2009 年時 点で東ウジュムチン旗はシリンゴル盟のなかで最もモンゴル族比率の高い旗 である。

注 6）調査を実施した 2008 年は北京オリンピック開催時で，国境付近となる 調査地では外国人の観光目的以外の立ち入りに制限があった。そこで，第一 次調査前半には政府関係者同席のもと調査を実施した。その後はガチャの住 民同士の紹介によって調査世帯を確保した。

注 7）聞き取り調査は寸心゙てモンゴル語で行い，それぞれ日本語↔モンゴル語 の通訳を入れている。第二次調査以降，一部においては通訳を入れず，漢語 を併用している。聞き取り項目は家族の基本属性，放牧形態，居住歴，ゲル やバイシンの使用状況等である。実測調査は第一次調査のみ配置図もとって いるがその他はゲル及びバイシンの平面図についてコンベックスやレーザー 距離計を用いて実測した。

注 8）シリンゴル盟では，1980～1984 年の間に人民公社で管理していた家畜 を世帯単位に分配した ${ }^{5)}$ (包产到户)。また，その後は段階的に牧地の使用・ 管理権も世帯単位に分配し，1989 年には全盟で各世帯の牧地面積が確定し た (畜草双承包)。1997 年には牧地の使用証も発行され ${ }^{6)}$ ，牧畜業は人民公 社単位の共同経営から世帯単位の個人経営へと完全移行した。

注 9）「退牧還草」政策とは，中国の牧畜地域において実施されているもので, 事業内容は主に「禁牧（一定期間，放牧することを完全禁止すること）」，「休 牧（牧草が萌芽から結実するまでの期間内において放牧を停止すること）」, 「区画輪牧（自然状況や人為的判断に基づき牧草地をいくつかの単位に区切 り，順次牧草地をかえて放牧すること)」の三つに分類できる ${ }^{9)}$ 。シリンゴ ル盟でも「囲封転移戦略」として，牧畜地域における退牧還草の適用と牧畜 民の第二・第三産業への転職促進, 牧草地の集約経営の推進等が行われてい る ${ }^{10)}$ 。

注 10）モンゴル族牧畜民は伝統的に，常設の住居としてのゲル以外にも，臨 時的な放牧（オトル）に用いる仮設の住居を用いることがある。世帯全員が 居住するゲルよりも簡易で，少人数用になることが多い。本論ではこれらも 放牧用の住居として包括的に捉え，ゲルとともに取り上げている。

注 11）このようなゲルは各地で呼び名が異なる。調査地では，ジャラントブ jararan tobo（ハリネズミの巣）と呼ぶ。 